\title{
Relationship Marketing and Switching Behavioural Intention Among the Customers of Deposit Money Banks in Nigeria
}

\author{
Esiti, Blankson Governor ${ }^{1} \quad$ Adeola A. Ayodele ${ }^{2}$ \\ 1.Department of Petroleum Marketing and Business Studies, Petroleum Training Institute, Effurun, Nigeria \\ 2.Department of Marketing, Nnamdi Azikiwe University, Awka Nigeria
}

\begin{abstract}
Service rendering, including banking services, in the world over is becoming competitive, because customers expect higher service delivery, tailored towards meeting their individual needs. Thus, Deposit Money Banks are developing strategies to keep customer from defecting to other competitors so as to remain in the business. This precarious situation of banks led to re-thinking of corporates management to developing long lasting relationship with customers that will enhance sustainability. This was when relationship marketing, (RM) came into prominence in the banking industry, thereby attracting attention from researchers and marketing practitioners. The purpose of this study, therefore, is to investigate the influence of relationship marketing dimensions (communication, commitment, trust and conflict handling) on customers' switching behavioural intention amongst selected Deposit Money Banks in Warri, Nigeria. A sample of 324 banks' customers were selected using judgement sampling technique from a total of 61 branches of 16 different Deposit Money Banks in Warri and its environs, and their responses were processed using the descriptive and inferential statistics of Ordinary Least Square regression technique. The study found out that there exists significant relationship between the dimensions of RM (commitment, communication, conflict handling and trust) and switching intentions of Deposit Money Banks' customers in Warri and its environs in developing a good relationship. Based on the findings, we recommended that management of Deposit Money Banks should increase their commitment strategies (like ensuring flexibility in serving customers and personalising service to suit customers' needs), communication strategies (like credit or debit alert messages, service failure and recovery messages), and intensify effort to improve conflict handling (like refraining from improper comments and never too-busy attitude of employees). All these strategies if adopted may lead to reduction of customer defection to other competitors'.
\end{abstract}

Keywords: Relationship Marketing, Commitment, Communication, Trust, Conflict Handling Behavioural Switching Intention, Deposit Money Banks, Nigeria.

DOI: $10.7176 / \mathrm{JMCR} / 72-03$

Publication date:October $31^{\text {st }} 2020$

\subsection{Introduction}

The hyper-competition in most industries including Banking Industry across the globe appears making relationship marketing (RM) becoming a core strategy to keep customers from defecting to competitors' brands. This is because $\mathrm{RM}$ offers a firm the flexibility of creating, developing, nurturing and maintaining lasting (long term) relationships with individual customers through the use of people and technology in creating the profiles of customers and their needs and treating the customers according to the needs. It is specifically defined as obtaining relevant information from existing and potential customers through people and technology to fast track the tailoring of products and services in line with individual customer tastes, needs, and styles (Nwokah \& Didia, 2015). RM is also about establishing and strengthening relationships with customers through efficient and effective delivery of superior service as well as demonstrating trust when creating and communicating products to customers (Koçoglu \& Kirmaci, 2012).

In Nigeria, Deposit Money Banks appears to have partially embraced relationship marketing (Adeyeye, 2013). Most banks in Nigeria are employing technologies to customize services according to customer requests and desires. They have been treating each customer individually by leveraging individual account information to tailor offerings as well as sending programs and messages that fit the specific needs of customers (Justin \& Adiele, 2013). This evident in the short message (SMS) alerts on birthday wishes customers receive from some banks as well as when they deposit money from the banks.

However, the success of RM is not just about identifying and messaging customers. But it is based on the practices of trust (integrity, benevolence, competency of the service provider make and keep promises); commitment (enduring desire to customized products to customers wants and needs), communication (timely provision of trustworthy information); and conflict handling (ability to avoid potential conflicts, solve manifest conflicts before they create problems, and discuss solutions openly when problems do arise) (Ndubisi, 2007). These practices are central to maintaining a valued relationship that is mutually satisfying and beneficial.

Elucidating on this, the success of RM has been linked to increasing customer loyalty (Malik. 2015; Krishnamoorthy \& Anandavel, 2014; Koçoğlu, \& Kirmaci, 2012; Khedkar, 2015), a phenomenon associated improvement in organization's customer base. Moreover, customer loyalty is an antipode of low switching 
intention, which is becoming a critical issue facing the banking industry. Switching intention is the decision conceived by customers to permanently or temporarily discontinue from patronizing one particular bank for another (Samrena, Abu, \& Saif 2016). Leaving one bank for another can become a serious setback for the losing bank present and future performance it cost five times more to acquire a new consumer than to retain an old one (Liu, Guo \& Lee, 2011). Consequently, retaining the current consumer base is much more attractive and viable than searching for new consumers (Lee \& Murphy, 2015). Zeeshan, Maleehah and Usman (2015) observed that initial investments on the customer (e.g. consulting or advertising costs) are wasted and further costs are required to obtain a new customer and these reduce firm's competitive position in terms of market share, earnings and profits. In light of this, we focused on the influence of RM on switching intention in the banking industry.

\subsection{Statement of Research Problem}

Series of complaint have been recorded in the banking industry in recent time. These include the untimely sending of SMS after a deposit has been made and unfair debiting of money from customers' accounts. They also include poor respond of mobile banking (M-banking) applications, Automated Teller Machine (ATM) and Point of Sales (POS) machines to customer needs. More disheartened is the unwillingness of banks to keep in touch with valued customers by providing timely and trustworthy information on service and service changes, and communicating proactively if a delivery problem occurs (Justin \& Adiele 2013). These complaints have also been compounded by the unfriendliness of customer's care as well as the failure of customer care in some banks to provide timely and honest responses and solutions to customer complains, which are an integral part of the development quality relationship according to Ndubisi (2007).

These challenges in the banking industry in Nigeria have carefully been explained and integrated into Ndubisi (2007)'s model of relationship marketing, but few empirical studies have tested the applicability of Ndubisi (2007)'s model of relationship marketing in the Nigeria banking industry. Moreover, while the commitment of most banks in Nigeria to RM is gaining prominence, there is little empirical insight of the influence of trust, communication, commitment and ability of banks through customer care to handle conflicts or complaints on switching intention in the banking industry. The few studies that have made attempt were Adeyeye, 2013, Justin and Adiele 2013, who focused on the influence of customer relationship management and bank performance in Nigeria. Consequently, this study tries to cover the gap other studies have not. In light of the stated problems, this study seeks to empirically investigate the nexus between relationship marketing and switching behavioural intention among deposit money banks' customers in Warri, Nigeria.

\subsection{Research Hypotheses}

The research hypotheses formulated in this study are stated in null form as:

$\mathrm{H}_{1}$ : There is no relationship between commitment dimension of RM and switching intention of Deposit Money Banks' customers in Warri.

$\mathrm{HO}_{2}$ : There is no relationship between the trust dimension of RM and switching intention of Deposit Money Banks' customers in Warri

$\mathrm{HO}_{3}$ : There is no relationship between the communication dimension of $\mathrm{RM}$ and switching intention of Deposit Money Banks' customers in Warri.

$\mathrm{H0}_{4}$ : There is no relationship between the conflict handling dimension of RM and switching intention of Deposit Money Banks' customers in Warri.

Literature Review

\subsection{Customer Switching Intention}

Customer switching has become a critical issue facing the banking industry. Its conceptual definition in the banking industry though not substantially different from other industries; switching intention is more intense in the banking and telecommunication industries than other industries (Roos \& Gustafsson, 2007). Switching intention is the decision conceived by customers to permanently or temporarily discontinue from patronizing one particular bank for another (Samrena, Abu, \& Saif., 2016). It is the decision of a customer to stop his/her loyalty from one bank to another (Kaeveney, 2015). Thus, brand switching could occur when customers move from one bank to another either on a temporary basis or on a permanent basis. This definition suggests that switching intention is opposite of customer loyalty, which Roos, Edvardson and Gustafson (2014) defined as the degree to which a consumer exhibits repeat purchasing behaviour from a service provider, possesses a positive attitudinal disposition toward the provider, and considers using only this provider when a need for this service arises. Moreover, Lee and Murphy 2015) classified consumer loyalty into hard-core and brand switchers, of which the brand switchers are the consumers who use two or more brands when a single brand does not satisfy all their needs. This is rampant in the banking industry as customers often maintain different accounts with different banks. However, for the purpose of this study, we operationalized switching intention as a customer's intention to stop maintaining or using their primary bank account for another. 


\subsection{Consequences of Switching From a Brand}

In most service contexts, customer switching is associated with negative consequences such as declining market share and poor profitability. Switching assumes additional significance in banking context as losing a consumer is a serious setback for the firm in terms of its present and future performance as the study indicates that it cost five times more to acquire a new consumer than to retain an old one (Liu, et al, 2011). Consequently, retaining the current consumer base is much more attractive and viable than searching for new consumers (Lee \& Murphy, 2015). Zeeshan, et al (2015) observed that initial investments on the customer (e.g. consulting or advertising costs) are wasted and further costs are required to obtain a new customer and these reduce firm's competitive position in terms of market share, earnings, and profits.

Nimako and Mbawuni (2016) further opined that customer defection has a stronger impact on revenue than on scale, market share, unit costs, and other factors that are usually associated with a competitive advantage. Furthermore, customer switching can bring negative word-of-mouth advertising which can hurt a bank's reputation and image (Lee \& Murphy. 2015). This is because customer switching is the opposite of customer retention and thus the longer a customer stays with an organization the more utility the customer generates and the higher the positive image of the organization. This utility is the outcome of a number of factors relating to the time the customer spends with the organization, including the higher initial costs of introducing and attracting a new customer; increase in the value of purchases, increase in the number of purchases, customer's better understanding of the organization and positive word-of-mouth promotion (Sathish, Kumar, Naveen, \& Jeevanantham, 2011).

Zeeshan, et al (2015) demonstrated the social and financial implications of customer switching behaviour and found a strong relationship between corporate image, customer switching behaviour and profitability. They reiterated that firms that meet all customers' requirements financially performed better. High service quality enhances customers' favourable behavioural intentions while simultaneously reduces their unfavourable intentions The implication of the above discussion is that with high service quality, customers are attracted and satisfied and these increased their propensity to stay longer with their service provider and thereby graduate from being a client to supporter and finally an advocate who could have a significant effect on the firm financial and market performance. Moreover, minimize the negative effects of defection and enhance long-term relationships with customers in the Nigerian Banking industry is not just a product of price, service quality, promotion but also the kind of relationship marketing embarked upon by the banks. This is the focus of this paper.

\subsection{Relationship Marketing: An Overview}

Relationship Marketing (RM) has evolved as strategies deployed by an organization to develop intimate relationships with customers with the primary aim of retaining them and minimize the rate of customer's defections to competitor' brands (Zaree, \& Darabpour, 2014). It is the use of information, process, technology, and people to develop (build) that maintain long lasting relationships with customers (Agbaje, 2017). It is the implementation of an integrated series of techniques to create, develop, nurture and maintain lasting (long term) relationships with individual customers (Krishnamoorthy \& Anandavel, 2014).

RM has to do with attracting; maintaining and enhancing customer relationships through the communication of customizing products according to individual customer's expectations/needs (Justin \& Adiele, 2013). It is about recognizing the customers, distinguishing the customers based on the information collected from the customers so as to treat them in a unique way (customization of service) as well as ensuring speedily and proactively communicate of service failures, service failure recovery, impeding service changes and service charges at every given point to the customers (Ndubisi, 2017). It is about establishing and strengthening relationships with customers through efficient and effective delivery of superior service as well as a demonstration of trust in customer value creations, which is usually characterized by openness, sincere concern, receptiveness to customer suggestions and fair dealing with customers during service delivery ( Koçoğlu \& Kirmaci, 2012).

From the foregoing, this study defined RM as acquiring, nurturing and retaining customers through a commitment to product customization, timely communication of product information, effective conflict handling and development of trustworthiness in addressing the specific needs of individual customers. Driven by people and technology, it is about collecting information from existing and potential customers so as to customize and timely deliver the customized products to the individual customer in order to create value for them. Relationship development, which is the essence of RM is enhanced when a firm first of collect and record customer information in order to categorise potential customers and existing customers according to their needs and expectations (Bashir, Aliyu \& Noor (2014). This knowledge gain from customers will help the service firms to customize or tailor their products, messages, promotion and advertising programs to suit the individual's needs.

\subsection{Theoretical Foundation}

This study was anchored on Relationship Marketing model by Ndubuisi (2007). Ndubisi in 2007 developed and tested a model of relationship marketing. The model suggests that a firm can develop and manage customer relationships through building trust, commitment, communication, and effective conflict handling, all leading to a 
satisfaction of the customer. In light of this, the research focuses on trust, commitment, communication, and conflict handling dimensions of RM. Each of these is explained below:

2.4.1 Trust

McKnight, Kacmar, and Choudhury (2004) theorised that trust is the degree to which customers confidently rely on a promise made by service providers. It is the belief that the other party will fulfil his/her obligations (delivery of service as promised) in the exchange relationship. It is the conviction that another party has the ability, integrity, and benevolence in fulfilling its promises (Adeyeye, 2013). In this regard, trust has historically been based on integrity, benevolence, competency of the service provider to deliver its promises (Velnampy \& Sivesan, 2012). Integrity is seen as honesty in communicating the quality of product delivery and charges associated with them (Malik, 2015). It also occurs when customers perceived firms to be devoid of opportunity behaviour such as communicating what the products cannot do by exaggerating the product performance, unauthorized debiting of account and involving in other forms of cheating behaviours like hidden charges (Krishnamoorthy \& Anandavel, 2014).

Benevolence is the degree to which customer belief firms show genuine concerned about customers feelings in a relational situation and are interested in more than just selling them goods to make a profit (Ndubisi, 2007). It is a degree to which firms care about customer welfare and have customer interest at heart when providing services to them, and are willing to go the extra mile to solve customer problems when unexpected problems arise (Adeyeye, 2013). It is the degree to which customers' perceived firms to be ready to sacrifice extra effort in solving service problems experienced by them(Malik, 2015).

Ability is the degree to which customers perceived that firms have the resources including skilled manpower, financial muscles, and technology to deliver its promise (Krishnamoorthy \& Anandavel, 2014). It is perceived competent in a firm to make not only promises by also to keep and fulfil them. In this regard, trust exists when a customer has confidence in firms (banks) ability/competent in terms of its skilled manpower, finances, and technology to deliver its promises (Malik, 2015). It is a belief among customers that the resources of firms (personnel, technology, and systems) have been deploying to initiate, maintain and strengthen the relationship with them (Velnampy \& Sivesan, 2012).

From the foregoing, trust occurs when customer confidently relies on banks to deliver service as promised. However, betrayal of this trust by the banks could lead to defection as the fulfilment of promises is not only imperative to maintain and strengthened the relationship with customers but equally important as a means of achieving their satisfaction, which is central to retaining the customer base and securing long-term profitability (Adeyeye, 2013). Indeed, while making promises may persuade customers to act in a given way but it is keeping and fulfilling the promises that are more essential to maintain and enhances an evolving relationship (Ndubisi, 2007).

\subsubsection{Communication}

Communication has been defined as timely, trustworthy, relevant and adequate provision of information with respect to how to use products, benefits associated with the use of the products and the negative consequences of using the products (Ndubisi, 2007). It has also been seen as proactively and timely provision of information on service problems occurrence, service charges and service changes to customers (Velnampy \& Sivesan, 2012). It is keeping in touch with valued customers through the provision of relevant, trustworthy, timely and adequate information about service failures and what the firms are currently doing to forestalls them. In service firms like banks, the information is usually communicated through Short Messages (SMS), email, voice and video calls (Ndubisi, \& Wah, 2005).

However, studies suggested many firms in Nigeria, especially in banks, usually withhold certain information from customers (Mu'azu, 2013; Nwokah \& Didia, 2015). Banks sometimes failed to provide accurate and adequate information about the quality of service offering to customers as cases have been reported in many headlines or newspaper that even when banks deduct money from customers account and are experiencing service failure, banks make no effort to send short messages to the affected customers (Punch, 2017). In relationship building, several studies have reported that when one party consistently provides insufficient, false and untrustworthy information, the relationship usually ends in deadlock (Ndubisi, 2007). The relationship development also barely migrates from initiation stages when the information communicated is not carefully designed, customized, enriched and delivered purposefully. On this basis, that study indicated relationship development is reinforced when firms provide customized honest, timely, adequate information to customers at every stage of service consumptions, which include pre-service encounter, during service encounter and after service encounter (Khedkar, 2015).

2.4.3 Commitment

One of the dimensions of managing relationship marketing is a commitment, which has been defined as the enduring desire and obligation to make a relationship succeed, mutually satisfying and beneficial (Nwankwo \& Ajemunigbohun, 2013). Commitment as sometimes labelled as relationship investments have also been defined as the degree to which firms have invested time, effort, and financial resources in developing a relationship with 
existing and potential customers (Khedkar, 2015). It is the readiness of firms to exert considerable effort on behalf of customers through the delivery of excellent quality services and personalizing/ customizing products to fit individual customers' needs (Wali, Wright \& Uduma, 2015). Adding to this, Ndubisi (2007) concurs that commitment is the sacrifices of worthwhile investments in building relationships with loyal or at least potentially loyal customers. The investments usually take in form of offering quality services, an offering of bonus, offering of a gift, award to customers and tailoring products to customer's requirements (Velnampy \& Sivesan, 2012). They also reflect putting extra effort to help customers solve their problems on time, providing them with immediate services right on demands as well as ensuring flexibility in the treatment of customers (Justin \& Adiele 2013).

When a firm is perceived to be highly committed to relationship development, it has been suggested customers reciprocate accordingly (Nwokah \& Didia, 2015). This response usually takes in the form of putting in extra effort to remain in the firm rather than searching for alternative firms to switch to. The nature of reciprocating by customers also takes in the form of spreading positive information (wide word of mouth) about the company and its products (Koçoğlu \& Kirmaci, 2012). Perceived commitment towards making relationship beneficial and satisfying also increase customers feeling of a deep sense of moral obligation to increase frequent purchasing intentions, low intention to defect, low sensitivity to the products price and higher obligation recommend the products of the firm to others (Gbadeyan, 2010).

\subsubsection{Conflict Handling}

Ndubisi and Wah, (2005: 550) defined conflict handling as the "supplier's ability to avoid potential conflicts, solve manifested conflicts before they create problems, and the ability to discuss solutions openly with customers when problems do arise'. Conflict handling is the ability of a service provider to provide a satisfactory resolution to conflicts by effectively solving customer's problems or conflicts when they occur (Bradford, \& Weitz, 2009). The techniques often deploy in handling conflicts usually include collaboration, confrontation, compromising and accommodation. Accommodation conflicts handling approach also referred to as smoothing over, yield losing or obliging, places emphasis on satisfying the customers concerns, while neglecting one's own position in conflict episodes; the collaboration conflicts handling strategy involve searching for integrative win-win resolutions of conflict that fully satisfy and mutually beneficial to both parties concerns(customers and service provider) in disagreement; the confrontation conflicts handling approach some time labelled as forcing, win-lose, dominating, competing, and contending, places a premium on one's own objectives, but limited attention is paid to the other party's(customers) goals; the compromising conflicts handling strategy also refers as problem-solving, synergistic and integrating, attempt to forgo searching for optimality for each of the parties by sacrificing, sharing, give-andtake or giving up something but also holding out for something to find a solution to a conflict(Bradford \& Weitz, 2009).

Irrespective of the strategies deployed in resolving conflicts occurrences, the ability of the service provider to handle conflict in satisfactory manners has been suggested to be a powerful indicator for initiating and strengthen the relationship with the affected customers (Krishnamoorthy \& Anandavel, 2014). It does not influence customers' loyalty but also their exit and voice as the study of Ndubisi and Wah (2005) indicated customers who are dissatisfied with conflict handling/resolution raise voice by telling a least eleven people of their experience, while those who are satisfied with problem/conflict resolution tell only three people. Ndubisi and Wah (2005) further indicated customers whose complaints were satisfactorily resolved often become more company loyal than customers who were ever dissatisfied with conflicts resolutions or handling. The study also found when customers experienced major complaints or conflicts and was resolved quickly, ninety-five percent (95\%) of these customers further repeat buying behaviour from the company and perceived the relationship with the company to be strengthened. This indicates that customers who register a complaint and were dissatisfied with the conflict handling terminate a relationship with the organizations and barely return or conceive the intention to remain loyal with the service provider.

\subsection{Empirical Studies}

Solomon (2014) examined the examined statues RM practices and how the different RM dimensions, which include trust, reciprocity, empathy, bonding, and responsiveness, affect customer retention. Using descriptive and inferential statistics to analyse the primary data obtained through questionnaire from 253 bank customers of private banks selected in Mekelle, Ethiopia which include Wegagen bank, Dashen bank and Abyssinia Bank, the study of Solomon (2014) found that five RM dimensions (trust, reciprocity, empathy, bonding, and responsiveness) do not only strongly correlate with one another but each of the dimensions significantly affects affect customers retentions. Their study demonstrated that poor supervision and monitoring of the quality of bank services, poor customization of products, not given attention to individuals customers, heavy reliance on suggestion boxes to get feedback from customers as well as poor network and technological advancement were the common challenges in the implementation and practices of RM.

Krishnamoorthy and Anandavel (2014) examined how RM affects customer satisfaction and customer loyalty in the banking Industry in the Theni District of Tamil Nadu state. Employing regression analysis to test data 
collected from the 300 customers of 3 selected retain banks in the Theni District of Tamil Nadu, the study found that trust, commitments, competence in conflict handling dimensions of RM dimensions positively and significantly affect customer satisfaction and customer loyalty.

Adeyeye (2013) examines the influence of RM on perceived bank performance, with the specific objective of verifying if the measuring variables of CRM (bonding, trust, commitment, communication) affect the performance of banks. Using T-test, Pearson's correlation, regression, to test the data collected with questionnaire from one hundred and thirteen employees of Guarantee (GT), Stanbic, Money Deposit Bank, Eco, UBA and Skye Banks in Oyo town, the study found that commitment, bonding, trust, communications jointly and independently predicted perceived organizational performance.

Velnampy and Sivesan (2012) examine the influence of customer relationship marketing on customer satisfaction using one hundred and seven customers of mobile service providing companies such as Airtel, Dialog, and Mobitel. After conducting correlation and regression analysed on the data collected, the study found that trust, commitment, empathy, and equity employed to measure customer relationship marketing affect customer satisfaction.

Ndubisi (2007) sampled 220 bank customers in Malaysia as well as employed multiple regression analyses assessed data gathered from sample respondents to find out the impact of four key constructs of relationship marketing (trust, commitment, communication, and conflict handling) on customer loyalty. The study found that four constructs of RM do not only significantly related to one another but also significantly impact and predict a good proportion of the variance in customer loyalty.

Padmavathy, Balaji, and Sivakumar (2012) develop a multi-item scale for measuring the customer relationship management effectiveness (CRME) in Indian retail banks and to examine its relationship with key customer response customer satisfaction, loyalty. The study found five dimensions of RM, namely, commitment, customer experience, process-driven approach, reliability, and technology-orientation. They also found that commitment, process-driven approach and reliability positively affect customer satisfaction while reliability has a direct association with both customer loyalty and customer satisfaction.

Malik (2015) investigates the impact of RM on customers' loyalty and retention in the Automobile Sector in India using a survey method, particularly questionnaire to collect data from 256 vehicles owners. Malik (2015) also used regressions to test his hypotheses. He found that trust, communication and commitment dimension of RM significantly that lead to customer loyalty for the automobile. He, therefore, recommends the need for ontime service delivery, promptness in handling repair work, friendliness, helpfulness, arranging replacements and prompt fulfilment of the obligation to customers to be the key factors to stimulate customer satisfaction.

\section{Methodology}

This study adopts the deductive research design, since we began the study with already existing theories in the subject matter. Thus, from the existing theories, questions and pre-determined responses were structured and administered to sampled respondents. This approach is what we referred to as survey, otherwise known as quantitative approach to the study. The survey research design was adopted. The study adopted it because of the need to collect responses from the sampled respondents at various branches of the Deposit Money Bank to achieve the objectives of this study. The population of the study comprises all the customers of Banks in Warri, Delta States, because of the cosmopolitan nature of the city, where almost all Deposit Money Banks' branches are located. Efforts made to obtain the total number of active customers that opened and are operating a bank account with Deposit Money Banks in Warri were not fruitful. Given that the total population of this study could not be ascertained, because banks considered such information as sensitive and could not divulge the totality of their population. Based on the fact that most of Deposit Money Banks were not ready to supply total numbers of their customers base, we first conducted a pilot survey by administering two hundred (200) questionnaires randomly to a randomly selected branches of all 16 Deposit Money Banks located in Warri. The result of this survey reveals that one hundred and thirty-eight (138) or $69 \%$ of the respondents are customers of the banks, while sixty-two (62) or $31 \%$ were not customers of the banks.

Consequently, to determine our sample size, the above statistics were imputed into the Topman formula as follows:

$$
\mathrm{n}=\frac{\mathrm{Z}^{2}(\mathrm{PQ})}{\mathrm{e}^{2}}
$$

$\begin{array}{cll}\text { Where } \mathrm{n} \quad & \begin{array}{l}\text { Required Sample Size } \\ \mathrm{z}\end{array} & \\ & & \begin{array}{l}\text { Standard deviation of the desired confidence } \\ \text { Interval of } 95 \%=1.96\end{array} \\ \mathrm{P} & = & \text { Probability of positive response } \\ \mathrm{Q} & = & \text { Probability of negative response } \\ \mathrm{e} & = & \text { Limit of standard error } 5 \%=0.05\end{array}$

Imputing the values above into the formula: 


$$
\begin{aligned}
& \mathrm{n}=\frac{(1.96)^{2}(0.69)(0.31)}{(0.05)^{2}} \\
& =\frac{3.8416(0.2139)}{0.0025} \\
& 0.0025 \\
& =\quad 0.82171824 \\
& 0.0025 \\
& =\quad 328.687296 \\
& =\quad 328 \text { Customers }
\end{aligned}
$$

The judgement sampling method was used to choose the bank customers for questionnaire administration. To arrive at the number of questionnaire to analyse the researcher administered 500 questionnaires to customers, doing on the spot banking activities in the sixteen (16) branches of Deposit Money Banks in Warri, Delta. Moreover, with help of a research assistance, we distributed copies of questionnaire to customers in each of the sample frames according to the number of branches of each of the bank in Warri. However only 324 copies of questionnaires were retrieved and certified good for analysis. The number of copies retrieved from the customers in each of the banks is showed below.

\begin{tabular}{|c|c|c|c|}
\hline $\mathrm{S} / \mathrm{N}$ & Variables & Operationalization of variables & Measuring scale \\
\hline & Trust & $\begin{array}{l}\text { This is operationally defined as the degree to } \\
\text { which customers confidently rely on a } \\
\text { promise made by Money Deposit Bank. }\end{array}$ & $\begin{array}{l}\text { The measured scale for each items } \\
\text { was five point Likert-scale such as } \\
\text { 1- strongly disagreed, 2- disagreed, } \\
\text { 3- not sure, 4-agreed and 5-strongly } \\
\text { agreed }\end{array}$ \\
\hline & Communication & $\begin{array}{l}\text { This is operationally defined as the degree to } \\
\text { which customers believe that Deposit } \\
\text { Money Banks timely provides information } \\
\text { on service problems occurrence, service } \\
\text { charges and service changes to customers. }\end{array}$ & $\begin{array}{l}\text { The measured scale for each items } \\
\text { was five point Likert-scale such as } \\
\text { 1- strongly disagreed, 2- disagreed, } \\
\text { 3- not sure, 4-agreed and 5-strongly } \\
\text { agreed }\end{array}$ \\
\hline & Commitment & $\begin{array}{l}\text { This is operationally defined as the degree to } \\
\text { which customers believe that Money } \\
\text { Deposit Bank have invested time, effort, and } \\
\text { financial resources in developing } \\
\text { relationship with them through the delivery } \\
\text { of excellent quality services and } \\
\text { personalizing/ customizing products to fit } \\
\text { their individual needs }\end{array}$ & $\begin{array}{l}\text { The measured scale for each items } \\
\text { was five point Likert-scale such as } \\
\text { 1- strongly disagreed, 2- disagreed, } \\
\text { 3- not sure, 4-agreed and 5-strongly } \\
\text { agreed }\end{array}$ \\
\hline
\end{tabular}

Table 3.1: Name of Banks, Number of Branches, Sampled Size and Valid Respondents

\begin{tabular}{|l|l|l|l|l|}
\hline S/N & Banks & No of branches & Sampled customers & Number of valid Respondents \\
\hline 1 & Access Bank & 8 & 50 & 41 \\
\hline 2 & Eco bank & 5 & 30 & 25 \\
\hline 3 & FCMB & 3 & 30 & 15 \\
\hline 4 & Fidelity & 3 & 30 & 16 \\
\hline 5 & First Bank & 12 & 70 & 61 \\
\hline 6 & GT Bank & 3 & 30 & 17 \\
\hline 7 & Heritage Bank & 1 & 10 & 8 \\
\hline 8 & Keystone Bank & 2 & 20 & 11 \\
\hline 9 & Polaris Bank & 2 & 20 & 10 \\
\hline 10 & Stanbic Bank & 2 & 20 & 13 \\
\hline 11 & Sterling Bank & 3 & 20 & 15 \\
\hline 12 & UBA & 5 & 50 & 26 \\
\hline 13 & Union Bank & 3 & 30 & 15 \\
\hline 14 & Unity Bank & 2 & 20 & 12 \\
\hline 15 & WEMA Bank & 1 & 10 & 8 \\
\hline 16 & Zenith Bank & 6 & 60 & 31 \\
\hline & Total & 61 & 500 & 324 \\
\hline
\end{tabular}

Source: Field Survey, 2019

\subsection{Operationalization and Measurements of Variables.}

The operationalization of variables is showed in table 3.2 below.

Table 3.2: Operationalization and Measurement of Variables 


\begin{tabular}{|l|l|l|l|}
\hline S/N & Variables & Operationalization of variables & Measuring scale \\
\hline & Conflict Handling & $\begin{array}{l}\text { This is operationally defined as the degree to } \\
\text { which customers believe that Deposit } \\
\text { Money Banks through its employees solve } \\
\text { manifested conflicts satisfactorily, address } \\
\text { complains in a just manner and polite when } \\
\text { handling complaints/conflicts }\end{array}$ & $\begin{array}{l}\text { The measured scale for each items } \\
\text { was five point Likert-scale such as } \\
\text { 1- strongly disagreed, 2- disagreed, } \\
\text { 3- not sure, 4-agreed and 5-strongly } \\
\text { agreed }\end{array}$ \\
\hline $\begin{array}{l}\text { Switching } \\
\text { behavioural } \\
\text { Intention }\end{array}$ & $\begin{array}{l}\text { This is operationally defined as having to be } \\
\text { loyal to one service provider but switched or } \\
\text { having the determination in switching to the } \\
\text { service provider's competitor }\end{array}$ & $\begin{array}{l}\text { The measured scale for each items } \\
\text { was five point Likert-scale such as } \\
\text { 1- strongly disagreed, 2- disagreed, } \\
\text { 3-not sure, 4-agreed and 5-strongly } \\
\text { agreed }\end{array}$ \\
\hline
\end{tabular}

Source: Authors' Construction (2019)

The research instrument for this study consisted of a structured questionnaire made up of multiple question with five point scale, from strongly disagree to strongly agree. The questionnaire contained questions related to switching intention and dimensions of RM. Items on switching intention were adapted from the scale on switching behaviour by Aydin and Ozer in 2005 while that of RM from Ndubisi (2007).

The validity of the instrument (questionnaire) was affirmed by experts in marketing research, since we adapted scales on switching behaviour by Aydin \& Ozer (2005), and components of relationship marketing from Ndubisi. In terms of reliability of the instrument, twenty (20) copies of the questionnaire were administered to pre-test the research instrument. The data collected from the retrieved questionnaire were tested with Cronbach's Alpha reliability test to determine the internal consistency of the questionnaire items. The Cronbach's Alpha value for each item on the questionnaire is shown in table 3.3 below.

Table 3.3: Cronbach's Alpha Reliability Test

\begin{tabular}{|l|c|}
\hline \multicolumn{1}{|c|}{ Variables } & Cronbach's Alpha \\
\hline Commitment dimension of CRM & .794 \\
\hline Trust dimension of CRM & .876 \\
\hline Communication dimension of CRM & .773 \\
\hline Conflict handling dimension of CRM & .804 \\
\hline Customer Satisfaction & .813 \\
\hline
\end{tabular}

The Cronbach's Alpha value for each item on the questionnaire shown above was achieved by imputing the coded data collected from the respondents on each variable (Trust, Commitment, Communication and Complaint Handling) into a reliability scale in SPSS. The results of the reliability tests were generated by the SPSS. In analysing the data collected, descriptive and inferential statistical methods were used in this study. The descriptive statistics were means and standard deviations (using Statistical Packages for Social Sciences, SPSS 25), while inferential statistics used include, a correlation and Ordinary Least Square (OLS) regression techniques. The inferential statistics (Ordinary Least Square Regression) was used to test the hypotheses of the study. The tests were conducted at a $5 \%(0.05)$ level of significance using E-View version 8.

\subsection{Model Specification}

The study builds on the model specified by Ndubisi (2007) but replaces customer loyalty with switching intention. The model for this study is specified as follow:

SWTCHINT $=f($ COMMIT, TRUST, COMMUCTN, CFLIHLN

In this study, the long-run equation is specified as follow:

SWTCHINT $=\beta_{0}+\beta_{1}$ COMMIT $+\beta_{2}$ TRUST $+\beta_{3}$ COMMUCTN $+\beta_{4}$ CFLIHLN + U

$\begin{array}{lll}\text { SWTCHINT } & = & \text { Switching Intention } \\ \text { COMMIT } & = & \text { Commitment dimension of RM } \\ \text { TRUST } & = & \text { Trust dimension of RM } \\ \text { COMMUCTN } & = & \text { Communication dimension of RM } \\ \text { CFLIHLN } & = & \text { Conflict handling dimension of RM } \\ \beta_{0} & = & \text { constant } \\ \beta_{1} \ldots \beta_{4} & = & \text { coefficients and prior signs of the independent variables } \\ U & = & \text { Error term }\end{array}$

The a priori expectations for our variables are $\beta 1, \beta 2, \beta 3, \beta 4,<0$. This indicates that all the dimensions of RM which forms the independent variables of this study are expected to have a negative relationship with Switching Intention, which is our dependent variable. 
Analysis and Results

Table 4.2 shows the descriptive statistics of the level of Switching Intention in Deposit Money Banking Industry in Warri, Delta State.

Table 4.2: The level of Switching Intention

\begin{tabular}{|l|l|c|r|}
\hline N/S & Statement & Mean & $\begin{array}{l}\text { Standard } \\
\text { Deviation }\end{array}$ \\
\hline 23 & $\begin{array}{l}\text { I am no longer comfortable to continue making my current primary bank as } \\
\text { my first choice in banking transactions }\end{array}$ & 3.4074 & .24694 \\
\hline 24 & I have thought seriously of leaving my current primary bank for another bank & 3.5617 & .29271 \\
\hline 25 & I feel that my current primary bank no longer deserves my loyalty & 3.5833 & .07426 \\
\hline & Overall mean & 3.517467 & 0.204637 \\
\hline
\end{tabular}

Source: Researchers' Field Work (2019), using SPSS version 25

Decision Rules Criterion: If the calculated mean is less than 3.00, it means that the level of switching intention among sampled employees is low. But if it is above 3.00, it means that the level of switching intention among sampled employees is high.

From the results in Table 4.2, the overall mean index for the level of switching intention among sampled customers is 3.517 with the standard deviation of 0.2046 . This mean scored of sampled respondents is above the criterion mean of 3.00. Hence, we accepted that the level of switching intention among sampled customers of Deposit Money Banks is high. Concerning the individual items/questions addressing switching intention, the mean score of all the items was above the criterion mean, which indicated that customers of Deposit Money Banks are considering leaving their primary banks for other banks.

Table 4.3 below shows a descriptive analysis of the RM decomposed into four dimensions, which include: commitment, trust, communication, and conflict handling.

Table 4.3: Descriptive Analysis of Dimensions of Relationship Marketing

\begin{tabular}{|c|c|c|c|}
\hline $\mathbf{S} / \mathbf{N}$ & Statement & Mean & SD \\
\hline & Commitment & & \\
\hline 1 & This bank makes adjustments to suit my needs & 2.0988 & .27714 \\
\hline 2 & This bank offers personalized services to meet my needs & 1.7685 & .05226 \\
\hline 3 & This bank is flexible when its services are changed & 2.3302 & .30925 \\
\hline 4 & This bank is flexible in serving my needs & 2.7531 & .38126 \\
\hline 5 & This banks usually send me wishes & 2.0062 & .26392 \\
\hline \multirow[t]{3}{*}{6} & This bank is genuinely committed to developing a good relationship with me & 2.0710 & .23840 \\
\hline & Overall mean & 2.1713 & 0.253705 \\
\hline & Trust & & \\
\hline 7 & This bank is very concerned with security for my transactions & 2.0309 & .22119 \\
\hline 8 & This bank's promises are reliable & 1.9136 & .08691 \\
\hline 9 & This bank provides services as promised & 2.1821 & .15950 \\
\hline 10 & This bank fulfils its obligations/promise to customers & 1.7407 & .04426 \\
\hline \multirow[t]{3}{*}{11} & I have confidence in this bank's services & 2.0586 & .27355 \\
\hline & Overall mean & 1.98518 & 0.15708 \\
\hline & Conflict handling dimension of CRM & & \\
\hline 12 & This bank tries to avoid potential conflict & 2.1204 & .23206 \\
\hline 13 & This bank tries to solve manifest conflicts before they create problems & 1.9383 & .18134 \\
\hline 14 & The bank openly discuss solutions when problems arise & 2.1852 & .30121 \\
\hline 15 & My complains are always address satisfactory & 2.1790 & .32096 \\
\hline 16 & This Bank treats me with polite manner when handling my complaints & 2.4290 & .30890 \\
\hline \multirow[t]{3}{*}{17} & The employees of this bank are never too busy to respond to my complaints & 1.7994 & .08745 \\
\hline & Overall mean & 2.10855 & 0.238653 \\
\hline & Communication & & \\
\hline 18 & This bank always provides me with trustworthy information & 2.0710 & .23840 \\
\hline 19 & This bank usually provides me information when there is new banking service & 1.9383 & .18134 \\
\hline 20 & This bank often provides me timely information like credit alerts & 2.8611 & .18394 \\
\hline 21 & This bank always provide me with accurate information & 2.7716 & .21025 \\
\hline \multirow[t]{3}{*}{22} & The bank often provide me with sufficient information about their services and charges & 2.7531 & .38126 \\
\hline & Total Mean & 2.47902 & 0.239038 \\
\hline & Overall Mean of Mean of RM & 2.181823 & 0.224307 \\
\hline
\end{tabular}

Source: Source: Researchers' Field Work (2019), using SPSS version 25 
Decision Rules Criterion: If the calculated mean is less than 3.00, it means that the level of commitment, trust, communication and conflict handling in Deposit Money Banks is low. But if it is above 3.00, it means that the level of commitment, trust, communication, and conflict handling is high. Table 4.3 showed that the overall mean index of relationship marketing (RM) is 2.181823, with a standard deviation of 0.2243 . This overall mean scored on relationship marketing as perceived by the sampled respondents is below the criterion mean of 3.00. Hence, the level of relationship marketing is low. Moreover, the mean scores of each of the constructs of RM are far below the criterion means of 3.00. This implies that the level of commitment, trust, communication, and conflict handling in Deposit Money Banks individually is low.

Hypotheses Testing

This study uses the results of the regression model conducted at a 5\% level of significance to test hypotheses formulated for this study. The decision rule is that if the calculated p-values (sig) are greater than $0.05(5 \%)$ level of significance, we accept the null hypothesis (H0). But if the p-values (sig) are less than $0.05(5 \%)$ level of significance accepts the alternate hypotheses (H1). The summary result of the test is presented in Table 4.4.

Table 4.4: RM and Switching intention in Deposit Money Banks

Dependent Variable: SWTCHINT

Method: Least Squares

Date: 08/06/19 Time: 02:22

Sample: 324

Included observations: 324

\begin{tabular}{lrrrr}
\hline \hline \multicolumn{1}{c}{ Variable } & Coefficient & Std. Error & t-Statistic & Prob. \\
\hline \hline C & 0.019597 & 0.106833 & 0.183437 & 0.8546 \\
COMMIT & -0.314945 & 0.022123 & -14.23621 & 0.0000 \\
TRUST & -0.004079 & 0.019336 & -0.210945 & 0.8331 \\
COMMUCTN & -0.297580 & 0.022276 & -13.35856 & 0.0000 \\
CFLIHLN & -0.355264 & 0.027019 & -13.14843 & 0.0000 \\
\hline \hline & 0.788230 & Mean dependent var & & 3.240463 \\
R-squared & 0.785574 & S.D. dependent var & & 0.568261 \\
Adjusted R-squared & 0.263140 & Akaike info criterion & & 0.183047 \\
S.E. of regression & 22.08834 & Schwarz criterion & 0.241392 \\
Sum squared resid & -24.65369 & Hannan-Quinn criter. & & 0.206335 \\
Log likelihood & 296.8371 & Durbin-Watson stat & & 1.633498 \\
F-statistic & 0.000000 & & & \\
Prob(F-statistic) & & & \\
\hline \hline
\end{tabular}

Source: E-View version 8 Data Output

The R-squared value of .788 displays in regression model indicated all the elements in the regression model which include: commitment (COMMIT), trust (TRUST), communication (COMMUCTN) and conflict handling (CFLIHLN) jointly explained approximately $79 \%$ of the systematic variation of switching intention in banking industry while other factors or elements not included in this regression model, but taken care of by the error terms accounted for $21 \%$. The R-squared value after adjustment for the degree of freedom was .786 in the regression model. This indicates commitment (COMMIT), trust(TRUST), communication(COMMUCTN) and conflict handling(CFLIHLN)) when grouped together explained approximately $79 \%$ systematic variations in variation switching intention sampled customers after the elements in the model have been adjusted to a degree of freedom.

The results in regression also showed commitment (COMMIT), trust (TRUST), communication (COMMUCTN) and conflict handling (CFLIHLN) when grouped together has F-statistic of 296.837 at Probability (F-statistic) value of .00000 which is less than 5\%. This means that at overall, there exist significant linear relationships between the dimensions of relationship marketing and switching intention in Deposit Money Banks in Warri, Delta State at a 5\% level of significance.

Individually, each of the dimensions of RM except trust (TRUST), had P-Values (Sig) of 0.00000, which is less than 5\% level of significance. Thus, the null hypotheses which states that there is no significant relationship between switching intention and the following RM dimensions: commitment (COMMIT), communication (COMMUCTN) and conflict handling (CFLIHLN) are rejected while the one which states that there is no significant relationship between Trust RM dimension and switching intention of customers is accepted. This means that each of the RM dimensions except trust (TRUST) significantly and negatively influences switching intention in the Deposit Money Banks at a 5\% level of significance. Durbin Watson-Statistic value in the regression model is 1.633 . This indicates no presence of serial correlation in the model, hence, the results in the model may be considered authentic, valid and reliable for decision makings. 
Correlation Analysis Result

A Pearson correlation analysis was further conducted to verify the relationship between the variables. The results of the correction analysis are shown in Table 4.5 below:

Table 4.5: Correlation Analysis Result

\begin{tabular}{|ll|l|l|l|l|l|}
\hline & & SWTCHINT & COMMIT & COMMUCTN & TRUST & CFLIHLN \\
\hline \multirow{5}{*}{ SWTCHINT } & Pearson Correlation & 1 & $-.696^{* *}$ & $-.634^{* *}$ & -.047 & $-.683^{* *}$ \\
& Sig. (2-tailed) & & .000 & .000 & .401 & .000 \\
& $\mathrm{~N}$ & 324 & 324 & 324 & 324 & 324 \\
\hline \multirow{2}{*}{ COMMIT } & Pearson Correlation & $-.696^{* *}$ & 1 & $.322^{* *}$ & -.017 & $.421^{* *}$ \\
& Sig. (2-tailed) & .000 & & .000 & .766 & .000 \\
& $\mathrm{~N}$ & 324 & 324 & 324 & 324 & 324 \\
\hline COMMUCTN & Pearson Correlation & $-.634^{* *}$ & $.322^{* *}$ & 1 & -.012 & $.331^{* *}$ \\
& Sig. (2-tailed) & .000 & .000 & & .828 & .000 \\
& $\mathrm{~N}$ & 324 & 324 & 324 & 324 & 324 \\
\hline TRUST & Pearson Correlation & -.047 & -.017 & -.012 & 1 & -.106 \\
& Sig. (2-tailed) & .401 & .766 & .828 & & .056 \\
& $\mathrm{~N}$ & 324 & 324 & 324 & 324 & 324 \\
\hline CFLIHLN & Pearson Correlation & $-.683^{* *}$ & $.421^{* *}$ & $.331^{* *}$ & -.106 & 1 \\
& Sig. (2-tailed) & .000 & .000 & .000 & .056 & \\
& $\mathrm{~N}$ & 324 & 324 & 324 & 324 & 324 \\
\hline
\end{tabular}

$* *$. Correlation is significant at the 0.01 level (2-tailed).

*. Correlation is significant at the 0.05 level (2-tailed).

Source: SPSS, 25 Data Output

The correlation matrix in Table 4.5 shows that switching intention is negatively and significantly related to all the RM dimensions: commitment (COMMIT), communication (COMMUCTN) and conflict handling (CFLIHLN) but not significantly correlated trust (TRUST) at 5\% level of significance. This further confirmed the results of the hypotheses tested in table 4.4 on the relationship between the dimensions of RM and the switching intention of customers of Deposit Money Banks in Warri.

\section{Discussion}

This study has provided empirical evidence on the relationship between relationship marketing (commitment, trust, communication, and conflict handling) and switching intention of customers of Deposit Money Banks in Warri. It shows the existence of a significant relationship between the dimensions (commitment, communication, and conflict handling, except trust) of RM when combined and switching intention. This finding is consistent with most extant studies, as found in our theoretical expectations, and theoretical framework of the study.

Empirically, the findings of this study that commitment constructs of RM, significantly and negatively affect the level of switching intention confirmed Krishnamoorthy and Anandavel (2014) empirical position that commitment dimensions of CRM positively and significantly affect customer satisfaction and customer loyalty in banking Industry in Theni District of Tamil Nadu State. It also aligned with Velnampy and Sivesan (2012) revelation that commitment measured of customer relationship marketing significantly and positively affect customer satisfaction in Airtel, Dialog, and Mobitel. This finding also collaborates with the study of Ndubisi (2007) commitment construct of relationship marketing significantly impact and predict a good proportion of the variance in customer loyalty among sampled 220 bank customers in Malaysia. Confirming this finding, Malik (2015) also showed that the commitment dimension of RM significantly impact on customer loyalty for the automobile in India among 256 sampled vehicle owners. Also a study conducted in Nigeria by Adeyeye (2013) demonstrated that commitment dimension of CRM had positive and significant influence on perceived bank performance in Guaranty Trust (GT), Stanbic, Zenith, Eco, UBA and Skye Banks in Oyo town.

The second findings of this study revealed that trust constructs of RM have no effect on switching intention however deviated with previous studies ( Ndubisi, 2007; Krishnamoorthy \& Anandavel, 2014; Malik, 2015; Solomon, 2014; Velnampy \& Sivesan, 2012). Extant studies specifically showed that the trust dimension of RM positively and significantly influenced customer satisfaction (Krishnamoorthy \& Anandavel, 2014; Velnampy \& Sivesan, 2012), Customer Loyalty (Ndubisi , 2017; Malik, 2015; Krishnamoorthy \& Anandavel, 2014) and customers retentions (Solomon, 2014).

The third finding of this study that confirmed the hypothesized relationship between communications constructs of RM and switching intention in Deposit Money Banks is consistent with Malik (2015) position that the communication dimension of RM is positively and significantly associated with customer loyalty. It also agreed with Solomon (2014) empirical revelation that the brand responsiveness construct of CRM positively and 
significantly affects customer retention. It further confirms Adeyeye (2013) study that the communication aspect of RM has a positive and significant influence on bank performance. More so, the findings of this study also collaborate with Ndubisi (2017) study showing that the communication construct of CRM significantly and positively relates and predicts a good proportion of the variance in customer loyalty.

The last finding of this study that conflict handling significantly and negatively affects switching intention confirmed that work of Krishnamoorthy and Anandavel (2014) that competence in conflict handling aspects of RM positively and significantly affect customer satisfaction and customer loyalty. It also corresponds with Ndubisi (2007) study of sampled 220 bank customers in Malaysia that conflict handling significantly impact and predict a good proportion of the variance in customer loyalty. This finding is also consistent with the study of Ndubisi and Wah (2005) that customers whose complaints were satisfactorily resolved often become more company loyal than customers who were never dissatisfied with conflicts resolutions or handling. Ndubisi and Wah (2005) revealed that when customers experienced major complaint or conflict and were resolved quickly, ninety-five percent (95\%) of these customers further repeat buying behaviour from the company and perceived the relationship with the company to be strengthened. This indicates that customers who register a complaint and were dissatisfied with the conflict handling terminate a relationship with the organizations and barely return or conceived the intention to remain loyal with the service provider due to dissatisfaction with conflict handling.

\section{Conclusions}

This study concludes that commitment, communication and conflict handling aspect of RM play an important roles in reducing customer switching or defection in the Deposit Money Banks in Warri, Delta State. It specifically concludes that more Deposit Money Banks sacrifice effort (committed/obligated) to treat customers in a unique way by customization of service, the more the bank mitigate customers defection. Other conclusions drawn from our findings are that defection rate in Deposit Money Banks in Warri, Delta State decreases with an increase in the provision of speeding and proactive communication on service failures, service failure recovery, service charges, impeding service changes as well as timely credit alerts on customer mobile phone. Moreover, we conclude that the ability of Deposit Money Banks to avoid potential conflicts, solve manifest conflicts before they create problems, and discuss solutions openly when problems do arise as well as receptive to customer suggestions and complain decreases the level of switching intention in the banking industry.

\section{Recommendations}

On the basis of the findings of this study, we made the following recommendations:

1 Management of Deposit Money Banks in Warri, Delta State, Delta States should increase its level of commitment in developing a good relationship with customer by adjusting and personalizing services to suit the needs of individual customer; sending wishes (birthday, Christmas, new-year, weekend wishes) to customers, and ensuring flexibility in serving the needs of customers, even when there are changes in services offering to customers.

2 Management of Deposit Money Banks in Warri, Delta States should also improve their efforts in ensuring quality communication in the relationship development with customers. This can be done by sending credit alerts, include services charges to customers on time. It can also be improved by intensifying effort in communicating service failures, service failure recovery, impeding service changes and services charges to customers. Such communication must be accurate, timely and adequate.

3 Management of Deposit Money Banks in Warri, Delta States should also intensify effort to improve conflicts handling in stimulating relationships with customers. It should ensure that its employees avoid potential conflict, address complains in just and satisfactory manner, polite when handling complaints (refrain from improper remarks(comments) when handling complains), never too busy to respond to complaints, openly discuss solutions with customers when problems arise as well as solve manifest conflicts in a considerate and truthful manner before they create problems.

4 Despite the fact that trust is not significant from this study, management of Deposit Money Banks in Warri, Delta States should still increase the level of trust in the relationship develop with customers by delivery services to customers as promised, ensuring fulfilment of the obligation enter with customers at every given time, dealing with a customer with sincerity and ensuring that transactions conducted by customers are secured.

Contributions to Knowledge

This study has made modest contributions to the body of knowledge by:

1 Throwing light on the degree to which RM linked to switching intention in Deposit Money Banks in Warri, Delta State. This has received insufficient attention as most previous studies mainly concentrated on the influence of relationship marketing on customer loyalty, and were done outside Nigeria.

2 Providing invaluable insight into the different dimensions (commitment, trust, communication, and 
conflict handling) of RM and the strength to which they influence switching intention in Deposit Money Banks in Warri, Delta State. This insight has not been given sufficient attention by extant studies, thus this may assist and direct management of Deposit Money Banks and other related organization in Nigeria on the dimensions of RM that has the greatest impact on switching intention in order to strategies toward improving the same in order to decrease the level of customer defection from bank to another.

3 Adding to the emerging body of knowledge and verifying existing results and hypothesized relationship between relationship marketing and behavioural intention and attitude (customer loyalty, customer satisfaction) conducted outside Nigeria. This knowledge may further stimulate the confidence of management of corporate organization with a view of promoting relationship marketing in order to address low attitude toward banks in Warri, Delta States and Nigeria as a whole.

\section{Limitation of Study}

Cognizance needs to be given to the possible limitations of this study, which may consequently affect the extent to which generalisations and conclusions can be drawn. The sample size, which was be limited only to Deposit Money Banks within Warri and its environs provide a constraint perception obtained from this study. The questionnaire did not include any questions on the relationship linked to reason for terminating an account with a bank. This may have enlightened additional aspects of the termination of the relationship between customers and their banks

\section{References}

Adeyeye, T, C. (2013). Impact of customer relationship management on perceived bank performance in Oyo Town, Nigeria. International Business and Management, 6 (2) 137-146.

Agbaje, Y. T. (2017). Customer relationship management and customer loyalty in Nigerian telecommunication industry. Business \& Management Review, 4(3), 80-93.

Aladejebi, O.A. \& Omonori, A.A (2015). Customer relationship management technology and small and medium enterprises in Ondo State, Nigeria. JORIND 13(2), 23-31.

Aydin, S., Özer, G., \& Arasil, Ö. (2005). Customer loyalty and the effect of switching costs as a moderator variable: A case in the Turkish mobile phone market. Marketing Intelligence \& Planning, 23(1), 89-103.

Bashir, D.S., Aliyu, O. A. \& Noor, A. H. (2014). A review of the inconsistency in CRM measurement: Evidence from the Telecommunication Industry. Journal of International Business and Economics, 2(2)107-131.

Bradford, K. D., \& Weitz, B. A. (2009). Salespersons' management of conflict in buyer-seller relationships. Journal of Personal Selling \& Sales Management, 29(1), 25-42.

Gbadeyan, R. A (2010). Customer relationship management and hospital service quality in Nigeria. An International Multi-Disciplinary Journal, 4(2), 168-184.

Homans, G. (1961). Social Behaviour: Its Elementary Forms. New York: Harcourt Brace Jovanovich.

Jacobsen, D., Olsson, M, Sjovall, A. (2004). The creation of customer loyalty: A qualitative Research of the bank sector, A Bachelor of Science Project, Kristiansand University, Department of Business Studies.

Justin, M.O. G, Adiele C. K., (2013). Customer relationship management and bank performance in Nigeria: An empirical validation study. International Journal of Science and Research (IJSR), 2(1), 59-69.

Kaeveney, S. M. (2015). Consumer switching behaviour in service Industries: An exploratory study. Journal of Marketing, 59, 71-82.

Khedkar, E.B. (2015). Effect of customer relationship management on customer satisfaction and loyalty. Journal Impact Factor, 6(5) 01-07.

Koçoğlu, D., \& Kirmaci, S. (2012). Customer relationship management and customer loyalty; a survey in the Sector of Banking. International Journal of Business and Social Science, 3 (3), 282-291.

Krishnamoorthy, V. \& Anandavel, V, (2014). Does customer relationship management improve customer satisfaction and customer loyalty in retail banking? Journal of Commerce \& Management 1 (8), 67-71.

Lee, R. \& Murphy, J. (2015). From loyalty to switching: Exploring determinants in the transition. Marketing Expert Journals, 36, 58-67

Liu, C.T., Guo, Y.M., \& Lee, C.H. (2011). The effects of relationship quality and switching barriers on customer loyalty. International Journal of Information Management, 31(4), 71-79.

Malik G. (2015). Impact of customer relationship management on customer loyalty and customer retention with reference to Automobile Sector. University Journal of Research, 01(01), 70-79.

McKnight, D. H., Kacmar, C. J., \& Choudhury, V. (2004). Dispositional trust and distrust distinctions in predicting high-and low-risk internet expert advice site perceptions. E-Service, 3(2), 35-58.

Mu'azu, S. B. (2013). Direct effect of service quality dimensions on customer satisfaction and customer loyalty in Nigerian Islamic Bank. Management, 3 (1): 6-11

Ndubisi , N. O. (2007). Relationship marketing and customer loyalty. Marketing Intelligence \& Planning, 25(1) 98-106. 
Ndubisi , N. O., \& Wah, C. K. (2005). Factorial and discriminant analyses of the underpinnings of relationship marketing and customer satisfaction. International journal of bank marketing, 23(7), 542-557.

Nimako, S, G., \& Mbawuni, J. (2016). Examining switching intentions, partial and total switching among mobile subscribers in Ghana. International Business Research 9 (5), 36-42.

Nwankwo, S. I., \& Ajemunigbohun, S. S. (2013). Customer relationship management and customer retention: empirical assessment from Nigeria's Insurance Industry. Business and Economics Journal, Bus Eco, 4(2), 3443

Nwokah, N.G \& Didia. J. U. D. (2015). Customer relationship management and marketing performance: The study of food and beverages firms in Nigeria. European Journal of Business and Management, 7(15), 85-92.

Oliver, R.L. (1980). A cognitive model of the antecedents and consequences of satisfaction decisions. Journal of Marketing Research, 17, 460-469.

Ndubisi , N., \& Kok Wah, C. (2005). Factorial and discriminant analyses of the underpinnings of relationship marketing and customer satisfaction. International journal of bank marketing, 23(7), 542-557.

Padmavathy, C. \& Balaji, M.S., \& Sivakumar, V.J. (2012). Measuring effectiveness of customer relationship management in Indian retail banks. International Journal of Bank Marketing, 30 (4), 246-266.

Roos, I. \& Gustafson, A. (2007). Understanding frequent switching patterns. Journal of Service Research 10 (1) 93- 108.

Roos, I., Edvardson, B., \& Gustafson, A. (2014). Customer switching patterns in competitive and non-competitive service industries. Journal of Service Research, 6(3), 256-271.

Samrena, J., Abu. B, A, H, \& Saif. U. R (2016). Switching Intentions: A Case of Saudi Arabian Hypermarkets. International Journal of Economics and Financial Issues, 5, 215-222.

Sathish, M, Kumar K.S., Naveen, K.J., \& Jeevanantham, V. (2011). A study on consumer switching behaviour in cellular service provider: A study with reference to Chennai. Far East Journal of Psychology and Business, 2(2), 71-81.

Saunders, M., Lewis, P. and Thornhill, A. (2003), Research Methods for Business Students, Harlow: Financial Times, Prentice Hall.

Solomon, A. (2014). Assessment of Customer Relationship Management Practices. Retrieved on the 12/04/2019 from https://opendocs.ids.ac.uk/.../Assessment\%20of\%20Customer\%20Relationship\%20Mana

Velnampy, T., \& Sivesan, S. (2012). Customer relationship marketing and customer satisfaction: A study on mobile service providing companies in Srilanka. Global Journal of Management and Business Research, 12(18), 75-85.

Wali, A. F., Wright, L.T, \& Uduma, I, A. (2015). Customer relationship management for brand commitment and brand loyalty. British Journal of Marketing Studies, 3 (4), 45-58.

Zeeshan, A., Maleehah, G, \& Usman, R, (2015). Factors affecting consumer switching behavior: mobile phone market in Manchester- United Kingdom. International Journal of Scientific and Research Publications, Volume 5, 2250-3153

Zaree, A., \& Darabpour, M. (2014). Impact of Customer Relationship Management on Customer Loyalty Chain Hotel. Kuwait Chapter of Arabian Journal of Business and Management Review, 33(2543), 1-16. 